\title{
Lessons from The French Exception: How Firms Choose Between Unitary and Dual Boards*
}

\author{
François Belot \\ Université Cergy-Pontoise \\ Edith Ginglinger \\ Université Paris-Dauphine \\ Myron Slovin \\ HEC Paris \\ Marie Sushka \\ Arizona State University
}

Keywords: board of directors, dual board, unitary board, corporate governance, monitoring, supervisory board, management board

JEL Classification: G32; G34

\footnotetext{
${ }^{*}$ We thank Eric de Bodt, François Degeorge, François Derrien, Ulrich Hege, Daniel Ferreira and seminar participants at Essec for helpful comments on this paper. The financial support of the Fédération Bancaire Française Chair in Corporate Finance is gratefully acknowledged.
} 


\title{
Lessons from The French Exception: How Firms Choose Between Unitary and Dual Boards
}

\begin{abstract}
Many governance reform proposals focus on strengthening board monitoring. In contrast, Adams and Ferreira (2007) and Harris and Raviv (2008) conclude that a passive board is often optimal. We examine determinants of board structure choice in France, where firms are free to choose between a unitary (passive) board and a dual (monitoring) board. We find firms with greater asymmetric information are likely to adopt a unitary board. Firms with a high potential for private benefit extraction are likely to adopt dual boards. Firms well monitored by financial market and institutional forces are less likely to have dual boards. Our results imply that freedom of contract about board structure is valuable for shareholders.
\end{abstract}




\section{The Lessons from The French Exception: How Firms Choose Between Unitary and Dual Boards}

\section{Introduction}

A key mechanism for resolving the collective action problem intrinsic to corporate governance is the delegation of control by shareholders to a board of directors, the entity charged with monitoring the firm's activities. Numerous proposals for reforming corporate governance have focused on strengthening board monitoring in the wake of corporate scandals such as the failures of Enron and WorldCom, the backdating of options, and the collapse of major financial firms (especially Lehman Brothers). ${ }^{1}$ These proposals take the basic structure of the board as given since national laws generally dictate whether a firm has a unitary or dual board structure. In the U.S., unitary board structure is universal, reflecting both state corporation statutes and the body of common law precedents. Other countries (e.g., Germany) mandate a dual board structure that consists of a supervisory board and a management board. Given such national constraints, there has been little empirical work as to how the basic structure of the board is determined. Instead, research has focused on the effects of various aspects of board configuration and composition.

Our paper provides insight about the determinants of basic board structure by analyzing the longstanding exception of France where a firm can choose to have a unitary or a dual board, or later reverse the decision, via a charter amendment. We investigate the determinants of board structure choice by examining a large sample of French public firms and analyzing how the choice relates to characteristics of the firm and its environment. The value of this work is enhanced by the EU's decision (in 2004) to allow a firm to incorporate (or reincorporate) as a European company, Societas Europaea (SE), with a unitary or dual board.

\footnotetext{
${ }^{1}$ Among the best known reports are the Cadbury Report (1992) in the UK and the Vienot Report (1995) in France, and there have been similar reports in many other countries.
} 
Recent academic research on how boards affect firm value generates conclusions that run counter to proposals for strengthening board monitoring. Within the context of a single board, the Adams and Ferreira (2007) and Harris and Raviv (2008) theoretical models imply that maximization of shareholder value generally entails a management friendly, unitary board except when there is a potential for large managerial private benefits, where efficiency calls for more intensive board monitoring. Within the broader context of board structure, Adams and Ferreira interpret their findings as establishing conditions that lead to the efficiency of a dual board structure, which separates the advisory and monitoring functions to allow each board to adapt to its distinct role, alleviating the problematic tradeoff between the two functions inherent in a unitary board structure. For U.S. firms, Faleye et al. (2010) argue that monitoring intensity of boards is largely driven by regulatory constraints. ${ }^{2}$ They report evidence that greater monitoring intensity leads to poorer acquisition performance, reduced innovation, and lower firm value, indicating the importance of the tradeoff between board monitoring and advising. ${ }^{3}$

Our paper analyzes the conditions under which firms adopt a dual versus a unitary board structure, and identifies firm characteristics that have a significant effect on board structure. Our findings support the Adams and Ferreira view that a dual board structure fosters monitoring, and we offer valuable perspective about a corporation statute that allows freedom of contract for shareholders with respect to the choice of board structure. In addition, France provides a natural experiment to test whether permitting a unitary board to separate the positions of Chairman and CEO, is a substitute for the monitoring of a dual board structure.

Hermalin and Weisbach (1998), Adams and Ferreira (2007), and Harris and Raviv (2008) argue that corporate governance arises as a solution to the firm's value optimization problem,

\footnotetext{
${ }^{2}$ An example of such regulatory forces is the fact that the New York Stock Exchange requires that boards of listed companies have a majority of independent members.

${ }^{3}$ Faleye et al. (2010) define a monitoring intense board as one in which a majority of independent directors serve on at least two of three principal oversight committees: audit, compensation, and nominating,
} 
within the bounds of corporation law. Given freedom of contract, board structure should be an efficient response to the environment in which the firm expects to operate. Shareholders in France choose all of the members of the supervisory board, consistent with the Adams and Ferreira orientation, which assumes that the preferences of shareholders and the optimal supervisory board are aligned. ${ }^{4}$ Our study provides a rich tableau about board structure choice and the factors that influence this choice. An important aspect of corporate governance is ownership structure. La Porta et al. (1999) report that among the world's major stock markets, including France, many large public firms have dominant shareholders who are likely to influence decision-making. However, most studies of boards and corporate governance focus on the U.S., where firms typically have dispersed ownership structures (reflecting the prevalence of passive institutional investors) that foster the dominance of professional managers but may also facilitate the extraction of private benefits. ${ }^{5}$ As a result, conventional wisdom in the U.S. is that in practice many boards are captive to managers, given their informational advantage, the role they have in selecting directors, and the inability of most directors to devote the time and effort needed to make well-informed decisions on complex business matters. Absent deteriorating firm performance, these factors lead to passive boards that focus on advising and incentivizing executives, behavior that Adams and Ferreira (2007) and Harris and Raviv (2008) conclude is efficient, except when the potential for substantial private benefit extraction exists.

Our analysis of the choice between a unitary versus a dual board structure at French firms entails logit regressions. Overall, our empirical results are in close accord with the Adams and Ferreira model and suggest that firm characteristics have a significant effect on unitary versus

\footnotetext{
${ }^{4}$ In Harris and Raviv (2008) it is assumed that outside directors perfectly represent the firm's shareholders. Unlike France, in Germany, depending on firm size, a third or half of the members of the supervisory board represent the employees, so ipso facto, the supervisory board cannot be fully aligned with shareholder interests.

${ }^{5}$ An exception is McCahery, Starks, and Sautner (2010) who collect survey data from 90 Dutch and U.S. institutional investors about corporate governance preferences, including board structure.
} 
dual board structure. This evidence implies that it is efficient for firms to have the freedom to choose board structure rather than having a statute or a regulation that imposes uniformity. We find that when asymmetric information is severe, i.e., information costs are high, firms adopt a unitary board structure. Thus, high tech firms, firms with high Tobin's Q values, and those with research and development expenditures, tend to have unitary boards. In contrast, when the potential for private benefit extraction is high, using metrics such as media-based activities and firms with economic significance in their geographic area, dual boards are adopted to encourage greater board monitoring, We also find that firms that have substantial interaction with financial market forces, such as bondholders or lenders where monitoring is intrinsic to their function, are less likely to have a dual board, implying less marginal benefit from board monitoring. Likewise, French firms listed on a major U.S. stock exchange are held to higher disclosure standards and exposed to potential shareholder litigation, a factor that mitigates the private benefits problem, lessens the gains from board monitoring, and increases the likelihood of a unitary board structure. For closely held firms, a unitary board structure is more likely when the CEO is a member of the control group, but those led by professional managers are more likely to have dual boards, implying a need for greater board monitoring. We also present evidence that the sensitivity of CEO turnover to firm performance is significantly greater with a dual board, confirming the greater monitoring intensity of such a board structure.

The remainder of the paper is organized as follows. In Section 2, freedom of contract in relation to choice of board structure is discussed. In Section 3, hypotheses and predictions are developed. In Section 4, data collection is explained. Empirical results are reported in Section 5. Section 6 provides conclusions. 


\section{Freedom of contract: The choice of a board structure in France}

In the U.S. a single board structure is mandatory, whereas other countries (e.g., Germany) mandate a dual board structure for most public firms. ${ }^{6}$ The view that having a choice between board structures can further shareholder interests suggests that statutes that mandate a uniform standard are less efficient than statutes that allow freedom of contract with respect to board structure. Despite the different legal mandates about board structure, there is no empirical work on the choice of unitary versus dual structures. Nevertheless, this issue has become particularly relevant given the EU's initiative in late 2004 that allows incorporation or reincorporation as a European company (SE), with the option of a single or a dual board structure. ${ }^{7}$

In France a firm chooses the type of board structure when it is created and can alter the structure at a later date by an amendment to the Articles of Association (the charter) which requires a two-thirds vote of shareholders at an Extraordinary General Meeting. ${ }^{8}$ It is a board decision to submit this amendment; if there is a dual board structure, both the management and supervisory boards must approve. ${ }^{9}$ For dual board firms, the supervisory board (conseil de surveillance) nominates the members of the management board (directoire), which includes the CEO, controls the management board, and can veto some of its decisions. Managers can be members of unitary boards but not of supervisory boards. Reflecting the global trend toward separating the positions of CEO and Chairman (especially in the U.K. and to some extent in the

\footnotetext{
${ }^{6}$ Austria, The Netherlands, and Denmark mandate two-tier boards, whereas UK, Ireland, Spain, Sweden require unitary boards. In Germany, firms with over 2,000 employees have a management board (Vorstand) composed of full-time corporate executives that meet frequently and a supervisory board (Aufsichtstrat) that meets several times a year. Half of the members of the supervisory board represent the employees and half represent the shareholders.

${ }^{7}$ For a description of this new European company structure, see the report commissioned by the French Minister of Justice, Noëlle Lenoir (2007).

${ }^{8}$ Prior to this, the Works Council and the governance committee (if it exists) must be consulted. Under French law, there are two types of general meetings. Decisions by ordinary meetings, which approve the accounts, appoint and dismiss directors, and decide bond issues, require a 50\% majority vote. Extraordinary meetings pertain to decisions amending the charter and issuing shares and require a two-thirds majority vote.

${ }^{9}$ The number of directors is also established by charter, but it must be between three and 18 (before 2001 between three and 24). A director's term cannot exceed 6 years, and staggered boards are permitted.
} 
U.S.), ${ }^{10}$ since 2001 French firms with a unitary board have been allowed this flexibility.

\section{Literature, hypotheses and predictions}

\subsection{Theory on boards}

Our empirical work draws on the two approaches to boards found in early research: the agency approach (Berle and Means (1932), Jensen and Meckling (1976) and Fama and Jensen (1983)) and the managerial hegemony approach (Mace (1971) and Bebchuk and Fried (2004)). In the agency approach, a separation of ownership from control results from the dispersed ownership of modern corporations, leading to conflicts of interest between executives and shareholders, such as managerial risk aversion due to their considerable firm-specific capital, whereas shareholders hold diversified portfolios. To counter agency difficulties, governance mechanisms have emerged, some external (e.g., monitoring institutions) and some internal (e.g., incentive compensation schemes). In this view, to maximize value boards monitor managerial activities and reduce agency costs, taking into account the tradeoff between managerial discretion and board monitoring; i.e., managers can be expected to be opportunistic, but overmonitoring can be harmful to managerial initiative.

In the managerial hegemony approach the board is a passive body that lacks de facto authority over the CEO, reflecting dispersed shareholder ownership. Since managers have operational control, they have more precise knowledge about the firm and its environment relative to directors, and thus in effect control the firm and have considerable discretion. A friendly board passively approves managerial decisions, unless the firm sustains reverses or financial distress. ${ }^{11}$ Moreover, managers typically select board members, encouraging their loyalty, and directors have other outside responsibilities, limiting their ability to monitor or to

\footnotetext{
${ }^{10}$ See for example Brickley et al. (1997), and Dey et al. (2009).

${ }^{11}$ Vafeas (1999) reports evidence that boards become more active when there is a decline in the firm's share price.
} 
challenge CEO actions. $^{12}$

Adams and Ferreira (2007), Fluck and Khanna (2008), and Harris and Raviv (2008) develop formal information-based governance models that explain how shareholder interests may be best served by a passive board. Fluck and Khanna argue that this passivity is efficient due to the severity of the free rider problem generated by the costs of collecting information and making decisions in a group context. Harris and Raviv examine the tradeoff between agency costs and the value of insiders' information and conclude that if insiders have important information relative to outsiders, shareholders will prefer an insider-controlled board to a more independent board. Adams and Ferreira model the board as an entity that has a role in advising managers but also in monitoring and evaluating them. Given the intrinsic conflict between these functions and the board's dependence on CEO-supplied information, Adams and Ferreira find a management friendly board is efficient except when managers can extract substantial private benefits at a cost to dispersed shareholders. In this view, for firms with certain characteristics, it is optimal for the monitoring and advising functions to be separated, such as through the use of a dual board structure. ${ }^{13}$ Since the diversity of activities and characteristics across firms implies different levels of asymmetric information, private benefits, and external monitoring, the usefulness of the active monitoring intrinsic to a dual board structure should vary across firms. This perspective is also consistent with the tradeoff analyzed by Harris and Raviv, who view an outsider-controlled board as optimal when agency costs are large, although their modeling takes a single board structure as a binding constraint and independent directors are a proxy for outsider control. Fluck and Khanna (2008) argue that shareholders are better off by inducing optimal effort by managers (such as via compensation policies), and having a passive unitary board (with

\footnotetext{
${ }^{12}$ In the U.S. most corporate charters limit director liability to breaches of duty and firms routinely purchase insurance policies for directors and officers, largely eliminating their vulnerability to shareholder lawsuits.

${ }^{13}$ Adams and Ferreira (2007) extend these results by explicitly analyzing the impact of CEO ownership and private benefits on the incentive of the CEO to share information with the board and they derive implications for the optimal amount of board monitoring as a function of these factors.
} 
low, fixed director compensation), given the severity of the free riding problem.

\subsection{Board structure choice: Asymmetry of information and private benefits}

Board members are more reliant on the CEO when information asymmetry is high.

Duchin et al. (2010) find that the effectiveness of outside directors depends on the cost of acquiring firm information; i.e., when the cost is low, adding outsiders improves performance, but when the cost is high, adding outsiders worsens performance. Raheja (2005) and Masulis and Mobbs (2010) argue that inside directors facilitate information flow, so a management friendly board is efficient because it strengthens the incentive for insiders to reveal their private information. Thus, firms with considerable information asymmetry optimally have friendly boards with a higher proportion of insiders. Coles et al. (2008) find that insiders are valuable in high R\&D firms, where private information is important. Linck et al. (2008) find that firms with high growth opportunities, high R\&D expenditures, and high stock return volatility, all measures of asymmetric information, have smaller and less independent (i.e., friendlier) boards.

These studies argue that a lessening of the severity of asymmetric information increases the probability board members can usefully monitor, implying for our study a greater likelihood of a dual board, a structure more conducive to director information collection and monitoring. Thus, we specify proxy variables for asymmetric information. To measure a firm's investment alternatives, which are likely to be correlated with asymmetric information, we specify qualitative variables for firms with high $R \& D$ expenditures or those in the high tech sector. We include Tobin's Q, firm market value to replacement cost, to measure growth options, and the standard deviation of share price, to measure risk and asymmetric information.

Private benefits (such as insufficient effort, empire building, and self-dealing), while difficult for shareholders to evaluate (Grossman and Hart, 1988), play a key role in the Adams and Ferreira (2007) and Harris and Raviv (2008) models. From previous studies, we specify a 
variable for firms with eponymous names, given the Gompers et al. (2010) view that insiders place a high value on private benefits at firms named for an individual in the control group. ${ }^{14}$ Using ICB (Industry Classification Benchmark) codes, we specify a qualitative variable for media firms, given the Demsetz and Lehn (1985) view that control of such firms provides nonpecuniary income (e.g., influence over public opinion and notoriety for their executives).

We specify two alternative geographic variables based on Ehrhardt and Nowak's (2003) finding that private benefits (social recognition and prestige) are associated with large employers headquartered in relatively small cities. One variable is for firms headquartered in a small-sized city. The other metric, based on Gompers et al. (2010), is the ratio of a firm's sales to the aggregate sales of listed firms located in the same locality (i.e., department, a French regional political jurisdiction), with a higher ratio implying greater private benefits.

Prior literature (DeAngelo and Rice (1983), Jarrell and Poulsen (1988), and Ruback (1988)) finds that a dual class voting structure fosters managerial entrenchment, facilitating extraction of private benefits, since insiders bear only a fraction of the cost of private benefits. From this perspective, differential voting structures imply a greater need for monitoring, and thus an increased likelihood of a dual board structure.

\subsection{Substitutes for board monitoring: Leverage, blockholders, and foreign listing}

Jensen (1986) contends that debt mitigates private information problems and lessens the extraction of managerial private benefits. Diamond (1984) and Dewatripont and Tirole (1994) argue that creditors are monitors that carry the threat of terminating managers (such as through bankruptcy or liquidation) if performance turns out to be poor, with control shifted to fixed claimants. As a result, firms with considerable leverage are likely to be closely monitored by

\footnotetext{
${ }^{14}$ Roosenboom and Schramade (2006) show that owner-managers of IPO firms tend to maintain a strong lock on control when the firm carries their own name.
} 
creditors, reducing the gain from, and thus the likelihood of, the intensive monitoring intrinsic to dual boards. To test this effect we specify a variable that measures firm leverage.

Grossman and Hart (1980), Shleifer and Vishny (1986), Admati et al. (1994), and Bolton and von Thadden (1998), argue that blockholders have an incentive to produce information about the firm and to monitor managers, thus reducing the rent seeking activities of managers. From this perspective, a large shareholder serves as a substitute for board monitoring. Blockholders are more common in France than the U.S. where institutional investors, such as pension funds, mutual funds, hedge funds, and related entities, hold the preponderance of U.S. corporate stock. Also U.S. institutional investors hold shares for shorter periods (Kojima, 1997) than French investors. Moreover, in the U.S., there are legal restrictions on institutions' ability to influence corporate practices, ${ }^{15}$ so they are not generally viewed as an important force for disciplining management. Some exceptions, e.g., CALPERS, at times have actively monitored managers. ${ }^{16}$ We specify a variable for the ratio of shares held by the largest shareholder to total shares. If a large shareholder is an effective substitute for board monitoring, it should reduce the likelihood of a dual board structure, whereas firms with dispersed structures should have a greater incentive to adopt a dual board structure to provide more effective monitoring. We note that in France double voting rights are allowed for shares held by the same investor for a number of years as specified in the firm's charter. ${ }^{17}$ These rights pertain to the holder, not the shares, since the rights are lost when such shares are sold, which raises the cost of exit, strengthening investor incentive to monitor the firm rather than trade (exit). Thus, double voting rights counter

\footnotetext{
${ }^{15}$ Black (1990) details federal regulations and restrictions that discourage shareholder actions and limit the ability of institutions and other blockholders to influence corporate outcomes. These restrictions discourage monitoring and are thought to lead institutions to prefer to sell their holdings in a poorly managed firm rather than attempt to influence management, a practice that is commonly referred to as the "Wall Street Rule."

${ }^{16}$ There is a large theoretical literature beginning with the work of Diamond (1984) that analyzes the role of financial intermediaries as delegated monitors that have the incentive and the authority to control management. For a survey of this literature, see Boot (2000). See Scharfstein (1988) for a formal analysis as to how takeovers reduce the informational monopoly of managers and facilitate the replacement of inefficient managers.

${ }^{17}$ See Burkart and Lee (2008) for a discussion of French voting rights.
} 
the fact that liquid markets weaken the incentive for large shareholder monitoring.

Financial research shows that a voluntary listing on a foreign market whose disclosure rules are stronger than the home country provides greater protection to minority shareholders, strengthens firm reputation, broadens the investor base, improves the terms on which firms can issue securities, and lowers the cost of capital. This bonding hypothesis (Coffee, 2002) suggests that a firm sends a positive and costly signal to dispersed shareholders and potential investors by cross-listing in the U.S. French firms with U.S. ADRs must register with the SEC, generate financial statements consistent with U.S. accounting standards, and are exposed to potential shareholder litigation. Such listings entail monitoring and lessen the likelihood of a dual board.

\subsection{Concentrated ownership in generational firms}

A considerable proportion of listed firms in France are closely held, reflecting ownership by multiple family branches and generations that typically persists for decades (LaPorta et al., 1999). Such control groups may value the option to pursue activities that do not enhance firm value or avoid profitable expansion that weakens their control. In some cases control group members have managerial positions and/or board seats, while others employ professional managers. Family-based firms in the U.S. are a smaller proportion of listed firms (Anderson and Reeb (2003) and Perez-Gonzalez (2006)) than in France and are typically small, founder-based.

Closely held firms could perform better than other firms because they can generate nonmonetary rewards to group members, but they could also underperform since group members may pursue personal goals rather than the interests of dispersed shareholders. Moreover, CEOs drawn from the control group are not selected from the full set of available CEOs. Villalonga and Amit (2006) find that closely held firms create greater value while the founder is the CEO, but minority shareholders are worse off at firms managed by a descendant, even if the founder becomes the Chairman. Bennedsen et al. (2007) find that CEOs drawn from the control group 
generally underperform relative to professional CEOs, especially at larger firms or firms in fastgrowing industries. Adams et al. (2009) identify a positive effect of founder CEOs on firm performance, but Anderson et al. (2009) find that founder and descendent-controlled firms exhibit negative performance except when ownership is dispersed. Anderson and Reeb (2004) find that firms with continued founding-family-related ownership and relatively few independent directors, perform significantly worse than non-family firms, but moderate family-related board presence benefits the firm. In their view, minority interests are best protected when independent directors monitor closely-held firms. This research implies that the choice of board structure should be sensitive to whether a firm is closely held and the role the control group plays. Moreover, the transition to another generation or to professional management may be associated with a change in board structure. Thus, we examine how the likelihood of a dual board structure is related to whether a French firm is closely held.

\section{Sample}

Our sample consists of firm board structure from 1998 through 2008 for all firms in the French SBF250 index, which includes the 250 firms with the largest market capitalizations and that are the most actively traded on the Paris stock exchange. Their aggregate market value represents on average (median) $92.5 \%$ (93.0\%) of the market capitalization of French firms. The sample, encompassing 415 firms, is an unbalanced panel since some firms are delisted, while others enter the index; we exclude 36 firms since 14 are incorporated outside of France and operate pursuant to another country's corporation laws, 13 are "sociétés en commandite par actions" that require a dual board, and 9 lack required data. Yearly data are collected as of December 31 for the sample, which comprises 379 firms and 3054 firm-years. Ownership structure information is collected manually from annual reports since the required data are often 
not available in commercial databases. ${ }^{18}$ Accounting data are from WorldScope; stock market data are from DataStream.

Descriptive statistics are reported in Table 1. In Panel A, the annual data show a gradual rise in the proportion of firms with dual boards; the maximum is $28.8 \%$ in 2005 . In Panel B, means (medians) of firm characteristics are reported for the full sample and disaggregated by unitary and dual boards. The two groups do not differ significantly in terms of leverage or largest shareholder stake, but there are significant differences in most of the other characteristics. In particular, firms with high levels of risk, asymmetric information, or external monitoring have unitary boards. In contrast, firms characterized by high potential for private benefits have dual boards. Closely held firms managed by first generation members tend to have unitary boards; those managed by descendants or professional managers tend to have dual boards.

\section{Empirical results}

We estimate a binomial logit model of the choice of board structure using the maximum likelihood method where the value function for the logit is specified as a linear function of firmspecific variables that serve as proxies for asymmetric information, the potential for private benefits of control, and the presence of external monitoring. The reported coefficients provide estimates as to how an increase in a specified variable affects the marginal likelihood that a firm utilizes a dual rather than a unitary board structure.

\subsection{Information asymmetry, private benefits, and sources of monitoring}

The Adams and Ferreira and Harris and Raviv theories imply that the greater the information asymmetry the greater the benefit to the firm when board members are passive and permit management to pursue its informational advantage. From this view, the likelihood of a

\footnotetext{
${ }^{18}$ For example, electronic databases do not provide detail on the voting structure of the firm shares.
} 
dual board structure should be negatively related to the severity of information asymmetry. In Table 2 the coefficients are significant for most of the information asymmetry proxies and are consistent with these models. The R\&D and high tech dummy variables are particularly strong, and firm size, firm age, volatility, and Tobin's Q also obtain significant coefficients with the correct signs. Only the liquidity variable fails to be significant. Taken together, the results suggest that young, smaller firms whose value is derived from growth options or intangible assets, implying greater asymmetric information, are more likely to utilize a unitary board. However, as a firm ages and grows in size the likelihood of having a dual board structure increases. Thus, the results suggest an inverse relationship between the likelihood of having a dual board and the degree of information asymmetry.

In 2001, firms with a unitary structure gained the right to separate the positions of Chairman and CEO; by 2008, $20.9 \%$ of sample firms chose this option. To assess whether this flexibility about leadership positions influences the choice of board structure, a post-2001 qualitative variable is specified. The coefficient is positive and significant, indicating that the likelihood of having a dual board becomes greater after 2000. Thus, the option to separate these two leadership positions is not a substitute for a dual board structure.

We specify several types of proxy variables to test Adams and Ferreira's proposition that a high potential for private benefit extraction implies a greater likelihood of dual board structure. One, firms in the media industry, a sector associated with private benefits, are more likely to adopt a dual board structure. Two alternative geographical variables are specified. One variable indicates firms located in relatively small population centers; the other measures the extent to which a firm dominates economic activity in its local geographic area. Each variable has a significant and expected positive sign. Also, firms with dual class voting rights, often viewed as fostering private benefits, have a significantly greater likelihood of a dual board structure. 
We specify variables that reflect external monitoring of the firm's activities, which should lessen the potential for private benefit extraction and thus lower the likelihood of a dual board structure. The leverage variable obtains negative coefficients that are marginally significant, suggesting a reduced likelihood of a dual board structure. The variable for a U.S. stock exchange listing has a negative and statistically significant coefficient.

We test the effect of large blockholders by specifying a variable for the proportion of shares held by the blockholder, taking into account whether or not the firm allocates double voting rights to long term equity holders. The coefficients of both variables are negative and strongly significant, indicating that the greater the blockholding, the less the likelihood of a dual board structure, a finding consistent with the view that blockholders are effective monitors. While the pattern of the coefficients is suggestive of a greater blockholder effect at firms with double voting rights, indicating that such rights could spur greater blockholder monitoring, the difference in the coefficients is not statistically significant.

Overall, the evidence supports the Adams and Ferreira (2007) and Harris and Raviv (2008) theories of board governance and suggests that firm characteristics have an important influence on board structure and the intensity of monitoring. ${ }^{19}$ Greater severity of asymmetric information is associated with a greater likelihood of having a unitary board structure, with its associated propensity for board passivity, whereas when the potential for private benefit extraction is important, there is a greater likelihood of having a dual board structure. Firms well monitored by external forces are less likely to adopt a dual board structure.

\subsection{Board structure in closely-held firms}

We examine the effects of closely held firms, a salient component of French, and many

\footnotetext{
${ }^{19}$ This evidence for French firms stands in contrast to findings reported by Faleye et al. (2010) that the intensity of board monitoring (measured by committee assignments of independent directors) by U.S. firms reflects regulatory constraints rather than corporate choice-making.
} 
other countries' corporate structures (La Porta et al., 1999), defined as firms with an individual or group of related individuals holding at least $10 \%$ of shares outstanding. Members of the control group have an incentive to be monitors rather than passive investors, but private benefit issues also arise, and if they hold managerial positions, they may lack business skills characteristic of top level professional managers who succeeded in competitive labor markets.

In Table 3, the qualitative variable for closely-held firms has a positive and statistically significantly coefficient, indicating a greater likelihood of a dual board structure. A qualitative dummy variable for eponymous firms (Gompers et al. (2010)) has the expected, positive and usually statistically significant coefficient, indicating a greater likelihood of a dual board. Several logit regressions contain variables that distinguish between closely-held firms where members of the control group actively participate in management versus firms managed by professionals. We also distinguish between firms where the founder or member of the first generation is the CEO versus those firms managed by their descendants. The results indicate that professional management has a significantly positive effect, implying a greater likelihood of a dual board structure with members of the control group, who typically have representation on the supervisory board, expected to actively monitor the firm's activities. When this variable is disaggregated by generation, we find that a firm managed by a descendant or inheritor is more likely to have a dual board structure, as is the case with professional management. In contrast, when there is a first generation CEO, the firm is less likely to adopt a dual board structure, indicating that passive board behavior is likely to be a characteristic of founder run firms.

We also estimate two logit regressions restricting the sample to closely-held firms. The results again indicate that professional management or management by subsequent generations has a positive effect on the likelihood of a dual board. Our results suggest that the transfer of control from the founder to another generation or to professional managers is likely to be 
associated with a change in the firm's governance structure from a unitary to a dual board, suggesting that active board monitoring is efficient for such firms. From a broader policy perspective, this reasoning implies that freedom of contract about board structure is valuable for closely-held firms because it gives shareholders the flexibility to alter the choice of board structure as conditions evolve over time, facilitating the transfer of managerial responsibilities between generations or to professional managers. ${ }^{20}$

\subsection{Dual boards versus split leadership positions in unitary boards}

We analyze whether the 2001 option to allow French firms with a unitary board structure to separate the positions of CEO and Chairman is a substitute for a dual board structure. Since board structure is a charter action requiring a shareholder vote, while leadership choices are board actions, the decision of a unitary board to appoint a single person or different individuals to the two positions can be viewed as a second (and in most cases easily reversible) stage of governance. Since these choices are in practice sequential, we estimate a sequential logit regression for the post-2000 period, including a logit regression that estimates the likelihood of splitting the leadership positions, conditional on the firm having a unitary board structure. ${ }^{21}$ Thus, the logit model estimates the unconditional sensitivity of the likelihood of choosing a (dual) board structure as a function of firm and environmental characteristics, and also the likelihood conditional on a unitary board structure being chosen, of separating or consolidating

\footnotetext{
${ }^{20}$ To provide some indication of the gain that can arise from facilitating transitions at closely held firms, we conducted an event study of decisions by such French firms to hire a professional manager as CEO. Consistent with results reported by Villalonga and Amit (2006) for the U.S., we find a positive two-day return of $1.30 \%$ ( $\mathrm{p}=0.18$ ) and a buy and hold return for the subsequent three years of $60.15 \%$, suggesting that this move to professional management has important valuation effects for these firms.

${ }^{21}$ It is not appropriate to estimate a multinomial logit since it assumes that the random errors for each choice are independent, i.e., the independence of irrelevant alternatives assumption. This assumption implies that the choice between two alternatives is independent of other choices, so that if one of the alternatives is removed the other alternatives will sustain a proportionate increase in their probability of being chosen. This assumption is not tenable in French circumstances since the choice of a dual board structure necessarily separates the two positions. Nevertheless, we also estimated a simultaneous choice multinomial model. The estimated coefficients (not included in the tables but available from the authors) suggest conclusions that are broadly similar to the sequential logit.
} 
the leadership positions. Given our focus on board monitoring, we test whether variables that explain the choice of board structure also explain the leadership choice decision, based on the hypothesis that a separate chairman could be expected to encourage greater board monitoring while a combined position may encourage board passivity. ${ }^{22}$

In Table 4, the sequential logit results closely parallel the earlier results. However, few variables that explain board structure also explain the leadership choice of unitary board firms. With respect to asymmetric information variables, the significantly positive effects of firm size and age variables suggest that small, young such firms tend to unify the leadership positions, but the high tech firm variable has the incorrect (positive) sign, suggesting that these firms tend to separate the positions. Moreover, none of the other asymmetric information variables has a significant effect on leadership choice. The variables that gauge monitoring also are not effective determinants of leadership choice. As for the measures of the potential for private benefits, only the variable for eponymous firms is significant with the expected (positive) sign. Closely-held firms with professional managers tend to split the leadership positions, while firms controlled by subsequent generations tend to unify the positions. Overall, there is little evidence that separating leadership positions within a unitary board structure is a substitute for a dual board structure.

\subsection{Evidence that dual board structure fosters intensive CEO monitoring}

We test whether French firms with a dual board structure provide more intensive monitoring than firms with a unitary board structure, based on the well established result that there is a higher probability of CEO turnover following periods of weak market-adjusted returns (Coughlan and Schmidt (1985) and Warner et al. (1988)). Given our findings about the

\footnotetext{
${ }^{22}$ There have been numerous empirical studies about the effectiveness of alternative leadership structures, but the consensus in the literature suggests that there is little systematic difference in performance between firms that separate the two positions from firms in which a single individual holds the two positions. For a review of a large set of such studies, see Dalton et al. (1998).
} 
determinants of board structure and the Adams and Ferreira proposition that a dual board has a comparative advantage at monitoring managerial performance, thus fostering more active monitoring of managers, we expect CEO turnover to be more closely related to performance for firms that have a dual board structure.

Logit regressions in Table 5 assess whether a dual board structure increases (decreases) the probability of CEO turnover in response to poor (superior) performance. The dependent variable is a binary variable that equals one for a firm year in which there is CEO turnover in the following year (293 cases), and zero otherwise. Consistent with prior literature we do not differentiate forced versus voluntary turnover. The results indicate that prior performance has a significantly negative effect on CEO turnover, consistent with prior findings in the literature. As expected, we find that CEO age has a positive effect on turnover and that there is significantly lower turnover at closely held firms. We include a variable for a dual board structure and focus on an interaction variable for firm prior share price performance and the presence of a dual board. This interaction term obtains a consistently large, significantly negative coefficient that is approximately twice the size of the coefficient of the performance variable, a finding that implies that the sensitivity of CEO turnover to firm performance is approximately three times greater for firms with dual boards than for firms with unitary boards. Our evidence is consistent with the Adams and Ferreira (2007) model that a dual board structure fosters more active monitoring.

The specification of an interaction variable for a unitary board structure and the separation of the CEO and Chairman positions, indicates little effect on the sensitivity of turnover to firm performance. Thus, the separation of the top leadership positions does not alter the sensitivity of CEO turnover to performance. This result is consistent with our prior evidence that the separation of leadership positions within a unitary board structure is not a substitute for the more active monitoring conducted by a dual board. We also find that an interaction variable 
between share price performance and closely held firms is not significant. Overall, we find that a poorly performing firm with a dual board structure has a significantly higher likelihood of sustaining CEO turnover, confirming the greater monitoring intensity of a dual board structure.

\subsection{Robustness}

We conduct several robustness checks. The results remain similar when the standard errors are adjusted for clustering at the firm level in the logit regressions. Since more than onehalf of the firm-year observations apply to firms that maintained the same board structure throughout the sample period, we re-estimate the logit specifications for this subsample to insure that the coefficient estimates are not driven by the set of firms that adopt a change in structure. In Table 6, the results parallel our earlier results. We also estimate a logit regression that excludes financial firms (13\% of the sample) and find the pattern of results is also similar to the earlier results. There is little effect on the results when yearly dummy variables are used rather than a single dummy variable for the years after 2000, or when the subperiods before and after 2001 are estimated as separate logits. We also estimate the effect on the choice of board structure when the French government is a shareholder in a firm. Share ownership gives the government direct access to precise information about the firm and its management, but the government also has political and economic interests that may induce it to pressure the firm to act in ways that are not be in the best interests of other shareholders. ${ }^{23}$ We specify a qualitative variable to indicate when the French government is the largest direct shareholder in the firm or its parent, which occurs in $6 \%$ of the sample. The significant, positive coefficient suggests that for these firms, there is a greater likelihood that of a dual board; the pattern of the other results remains the same.

\footnotetext{
${ }^{23}$ Research that focuses on the interaction of political influence and corporate governance includes studies by Bortolotti and Faccio (2009) and Faccio (2006).
} 


\section{Conclusions}

Overall, we find that the firm's choice of a unitary versus a dual board structure is well explained by the theoretical model of Adams and Ferreira (2007), and is also consistent with the Harris and Raviv (2008) model. More specifically, firms that can be characterized as having severe asymmetric information problems or access to non-board sources of effective monitoring tend to opt for a unitary board structure, while firms that have a major potential for private benefits extraction tend to utilize a dual board structure. Closely-held firms controlled by the founders or other first generation individuals tend to have a unitary board structure while those managed by descendants or professional managers tend to have a dual board structure. We also show that there is enhanced sensitivity of CEO turnover to firm performance when there is a dual board, evidence that indicates the greater monitoring intensity of a dual board structure. Our evidence indicates that the separation of leadership positions within a unitary board structure is not a substitute for the monitoring intensity of a dual board.

From a broader policy perspective, our paper implies that freedom of contract about board structure is valuable and that shareholders benefit from having the flexibility to be able to choose the corporation's board structure and to alter board structure as conditions evolve over time, in contrast to the conventional view of regulators that outsider-controlled boards are always to be preferred. As such, the recent initiative to allow a European firm to be registered in the countries of the European Economic Area (EEA), rather than in its home country, provides a firm with a valuable option about its governance since it offers the freedom to choose between a unitary or dual board. Thus, a firm located in an EU country where a unitary (dual) board is the only form of corporate governance permitted, now has the freedom to re-incorporate as an SE 
and choose a dual (unitary) board structure, thus averting the potential costs of a one size fits all home country requirement about board structure. 


\section{References}

Adams, Renée B., Heitor Almeida, and Daniel Ferreira. 2009. "Understanding the relationship between founder-CEOs and firm performance." Journal of Empirical Finance 16:136150.

Adams, Renée B., and Daniel Ferreira. 2007. "A theory of friendly boards.” Journal of Finance 62:217-250.

Admati, Anat R., Paul Pfleiderer, and Josef Zechner. 1994. "Large shareholder activism, risk sharing, and financial market equilibrium.” Journal of Political Economy 102:1097-1130.

Anderson, Ronald C., Augustine Duru, and David M. Reeb. 2009. "Founders, heirs, and corporate opacity in the United States.” Journal of Financial Economics 92:205-222.

Anderson, Ronald C., and David M. Reeb. 2003. "Founding-family ownership and firm performance: Evidence from the S\&P 500.” Journal of Finance 58:1301-1328.

Anderson, Ronald C., and David M. Reeb. 2004. "Board composition: Balancing family influence in S\&P 500 Firms.” Administrative Science Quarterly 49:209-237.

Bebchuk, Lucian, and Jesse Fried. 2004. Pay without performance: The unfulfilled promise of executive compensation. Harvard University Press, Cambridge.

Bennedsen, Morten, Kasper Meisner Nielsen, Francisco Perez-Gonzalez, and Daniel Wolfenzon. 2007. "Inside the family firm: The role of families in succession decisions and performance." Quarterly Journal of Economics 122:647-691.

Berle, Adolph A., and Gardiner C. Means. 1932. The modern corporation and private property. Mac-Millan, New York.

Black, Bernard S. 1990. "Shareholder passivity reexamined.” Michigan Law Review 89:520-608.

Bolton, Patrick, and Ernst-Ludwig Von Thadden. 1998. "Blocks, liquidity, and corporate control." Journal of Finance 53:1-25.

Boot, Arnoud W.A. 2000. "Relationship banking: What do we know?” Journal of Financial Intermediation 9:7-25.

Bortolotti, Bernardo, and Mara Faccio. 2009. "Government control of privatized firms." Review of Financial Studies 22:2907-2939.

Brickley, James A., Jeffrey L. Coles, and Gregg Jarrell. 1997. “Leadership structure: Separating the CEO and chairman of the board." Journal of Corporate Finance 3:189-220.

Burkart, Mike, and Samuel Lee. 2008. "One share-one vote: The theory." Review of Finance 12:1-49. 
Coffee, John C. 2002. "Racing towards the top? The impact of cross-listings and stock market competition on international corporate governance." Columbia Law Review 102:17571831.

Coles, Jeffrey L., Naveen D. Daniel, and Lalitha Naveen. 2008. "Boards: Does one size fit all?" Journal of Financial Economics 87:329-356.

Coughlan, Anne T., and Ronald M. Schmidt. 1985. "Executive compensation, management turnover, and firm performance : An empirical investigation." Journal of Accounting and Economics 7:43-66.

Dalton, Dan R., Catherine M. Daily, Alan E. Ellstrand, and Jonathan L. Johnson. 1998. "Metaanalytic reviews of board composition, leadership structure, and financial performance." Strategic Management Journal 19:269-290.

DeAngelo, Harry, and Edward M. Rice. 1983. “Antitakeover charter amendments and stockholder wealth.” Journal of Financial Economics 11:329-360.

Demsetz, Harold, and Kenneth Lehn. 1985. "The structure of corporate ownership: causes and consequences.” Journal of Political Economy 93:1155-1177.

Dewatripont, Mathias, and Jean Tirole. 1994. "A theory of debt and equity: Diversity of securities and manager-shareholder congruence." Quarterly Journal of Economics 109:1027-1054.

Dey, Aiyesha, Ellen Engel, and Xiaohui Liu. 2009. "CEO and board chair roles: to split or not to split.” Unpublished working paper, University of Chicago Booth School of Business.

Diamond, Douglas W. 1984. "Financial intermediation and delegated monitoring." Review of Economic Studies 51:393-414.

Duchin, Ran, John G. Matsusaka, and Oguzhan Ozbas. 2010. "When are outside directors effective?” Journal of Financial Economics 96:195-214.

Ehrhardt, Olaf, and Eric Nowak. 2003. "Private benefits and minority shareholder expropriation (or what exactly are private benefits of control?)." Unpublished working paper, Humboldt University and University of Southern Switzerland Lugano.

Faccio, Mara. 2006. “Politically connected firms.” American Economic Review 96:369-386.

Faccio, Mara, and Ronald W. Masulis. 2005. "The choice of payment method in European mergers and acquisitions." Journal of Finance 60:1345-1388.

Faleye, Olubunmi, Rani Hoitash, and Udi Hoitash. 2010. "The Costs of Intense Board Monitoring." Journal of Financial Economics, Forthcoming.

Fama, Eugene F., and Michael C. Jensen. 1983. "Agency problems and residual claims.” Journal of Law \& Economics 26:327-350. 
Fluck, Zsuzsanna, and Naveen Khanna. 2008. “A theory of corporate boards with endogenous information collection, optimal compensation and strategic voting: When do independent boards dominate rubberstamping ones?" Unpublished working paper, Michigan State.

Gompers, Paul A., Joy Ishii, and Andrew Metrick. 2010. "Extreme governance: An analysis of dual-class firms in the United States." Review of Financial Studies 23:1051-1088.

Grossman, Sanford J., and Oliver D. Hart. 1980. "Takeover bids, the free-rider problem, and the theory of the corporation." Bell Journal of Economics 11:42-64.

Grossman, Sanford J., and Oliver D. Hart. 1988. "One share-one vote and the market for corporate control." Journal of Financial Economics 20:175-202.

Harris, Milton, and Artur Raviv. 2008. "A theory of board control and size." Review of Financial Studies 21:1797-1832

Hermalin, Benjamin E., and Michael S. Weisbach. 1998. "Endogenously chosen boards of directors and their monitoring of the CEO." American Economic Review 88:96-118.

Jarrell, Gregg A., and Annette B. Poulsen. 1988. "Dual-class recapitalization as antitakeover mechanisms: The recent evidence." Journal of Financial Economics 20:129-152.

Jensen, Michael C. 1986. "Agency costs of free cash flow, corporate finance, and takeovers." American Economic Review 76:323-329.

Jensen, Michael C., and William H. Meckling. 1976. "Theory of the firm: managerial behavior, agency costs and ownership structure." Journal of Financial Economics 3:305-360.

Kojima, Kenji. 1997. Corporate governance: An international comparison. Hajime Printing.

La Porta, Rafael, Florencio Lopez-de-Silanes, and Andrei Shleifer. 1999. “Corporate ownership around the world." Journal of Finance 54:471-517.

Linck, James S., Jeffry M. Netter, and Tina Yang. 2008. "The determinants of board structure." Journal of Financial Economics 87:308-328.

Mace, Myles L. 1971. Directors: myth and reality. Harvard Business School Press, Boston.

Masulis, Ronald W., and Shawn Mobbs. 2010. "Are all inside directors the same? Do they entrench CEOs or facilitate more informed board decisions?" Journal of Finance, Forthcoming.

McCahery, Joseph, Laura Starks, and Zacharias Sautner. 2010. "Behind the scenes: The corporate governance preferences of institutional investors." Unpublished working paper, Tilburg University. 
Perez-Gonzalez, Francisco. 2006. "Inherited control and firm performance." American Economic Review 96:1559-1588.

Raheja, Charu G. 2005. "Determinants of board size and composition: A theory of corporate boards." Journal of Financial \& Quantitative Analysis 40:283-306.

Roosenboom, Peter, and Willem Schramade. 2006. "The price of power: Valuing the controlling position of owner-managers in French IPO firms." Journal of Corporate Finance $12: 270-295$.

Ruback, Richard S. 1988. "Coercive dual-class exchange offers.” Journal of Financial Economics 20:153-173.

Scharfstein, David. 1988. "The disciplinary role of takeovers." Review of Economic Studies 55:185-199.

Shleifer, Andrei, and Robert W. Vishny. 1986. "Large shareholders and corporate control." Journal of Political Economy 94:461-488.

Vafeas, Nikos. 1999. "Board meeting frequency and firm performance.” Journal of Financial Economics 53:113-142.

Villalonga, Belén, and Raphael Amit. 2006. "How do family ownership, control and management affect firm value?” Journal of Financial Economics 80:385-417.

Warner, Jerold B., Ross L. Watts, and Karen H. Wruck. 1988. "Stock prices and top management changes.” Journal of Financial Economics 20:461-492. 


\section{Appendix: Variable Definitions}

\begin{tabular}{|c|c|}
\hline Variable & Definition \\
\hline$\%$ SALES & $\begin{array}{l}\text { Sales of firm } \mathrm{i} \text { in year } \mathrm{t} / \text { total sales of the companies incorporated in firm i's département in year } \mathrm{t} \\
\text { (Source : Worldscope) }\end{array}$ \\
\hline A1 & $\begin{array}{l}\text { Dummy variable: equals } 1 \text { if the firm has a unitary board, with a Chairman serving as CEO } \\
\text { (Source : Authors' database) }\end{array}$ \\
\hline A2 & $\begin{array}{l}\text { Dummy variable: equals } 1 \text { if the firm has a unitary board and separates the Chairman and CEO positions } \\
\text { (Source : Authors' database) }\end{array}$ \\
\hline AGE & Number of years since firm’s IPO (Source : Authors' database) \\
\hline CEO AGE & Log(CEO age) (Source : Authors' database) \\
\hline CEO TENURE & Log $($ CEO tenure +1$)($ Source : Authors' database) \\
\hline $\mathrm{CHF}$ & $\begin{array}{l}\text { Dummy variable: equals } 1 \text { when (1) the largest shareholder owns at least } 10 \% \text { of the voting rights; (2) } \\
\text { this shareholder is a member of the control group (direct ownership) or is a closely-held company } \\
\text { (ultimate ownership, at the } 20 \% \text { threshold) (Source : Authors' database) }\end{array}$ \\
\hline CHF.MGT & $\begin{array}{l}\text { Dummy variable: equals } 1 \text { if the firm is closely-held and the CEO is a member of the control group } \\
\text { (Source : Authors' database) }\end{array}$ \\
\hline CHF.MGT.GEN1 & $\begin{array}{l}\text { Dummy variable: equals } 1 \text { if the firm is closely-held and the CEO is a } 1^{\text {st }} \text { generation member of the } \\
\text { control group (Source : Authors' database) }\end{array}$ \\
\hline CHF.MGT.HEIRS & $\begin{array}{l}\text { Dummy variable: equals } 1 \text { if the the firm is closely-held and the CEO is a } 2 \text { nd, third ... generation } \\
\text { member of the control group (Source : Authors' database) }\end{array}$ \\
\hline DBLE VR & $\begin{array}{l}\text { Dummy variable: equals } 1 \text { if the company's charter authorizes double voting rights, } 0 \text { otherwise (Source } \\
\text { : Authors' database) }\end{array}$ \\
\hline DS & Dummy variable: equals 1 if the firm has a two-tiered board structure (Source : Authors' database) \\
\hline DUAL CLASS & $\begin{array}{l}\text { Dummy variable: equals } 1 \text { if the company has issued non-voting shares or investment/voting certificates } \\
\text { (Source : Authors' database) }\end{array}$ \\
\hline EPONYMOUS & Dummy variable: equals 1 for an eponymous firm (Source : Authors’ database) \\
\hline HIGHTECH & $\begin{array}{l}\text { Dummy variable: equals } 1 \text { when the firm belongs to the High Tech sector (as defined by Faccio and } \\
\text { Masulis, 2005) (Source : Worldscope) }\end{array}$ \\
\hline INDUSTRY & Industry dummies, based on the 1-digit SIC code (Source: Worldscope) \\
\hline DUMMIES & \\
\hline LEVERAGE & Ratio (financial debts / total assets) (Source : Worldscope) \\
\hline LISTING USA & $\begin{array}{l}\text { Dummy variable: equals } 1 \text { when the company is listed on the NYSE, NASDAQ or AMEX (Source : } \\
\text { Datastream) }\end{array}$ \\
\hline LOG(AGE) & $\log ($ number of years since firm’s IPO + 1) (Source : Authors' database) \\
\hline LOG(MVE) & Log (market value of equity) (Source : Worldscope) \\
\hline MEDIA & $\begin{array}{l}\text { Dummy variable: equals } 1 \text { when the ICBSSC code of the company is } 5500 \text { (MEDIA) (Source : } \\
\text { Datastream) }\end{array}$ \\
\hline MVE (M€) & Market capitalization at the end of the fiscal year (in euros millions) (Source : Worldscope) \\
\hline PERF & Stock return - SBF250 index return for the year (Source : Datastream) \\
\hline POP20 & $\begin{array}{l}\text { Dummy variable: equals } 1 \text { when the number of inhabitants of the headquarters town is lower than } \\
20000 \text { (Source : INSEE, Worldscope) }\end{array}$ \\
\hline PRO.MGT & $\begin{array}{l}\text { Dummy variable: equals } 1 \text { if the firm is closely-held and the CEO is a professional manager (Source : } \\
\text { Authors' database) }\end{array}$ \\
\hline $\mathrm{R} \& \mathrm{D}$ & Dummy variable: equals 1 if the firm reports R\&D expenses (Source : Worldscope) \\
\hline REL.SPREAD & [Ask-Bid]/[(Ask+Bid)/2]*100 (annual average) (Source : Datastream) \\
\hline S1CFR & Direct cash-flow rights of the largest owner (in \%) (Source : Authors' database) \\
\hline STATE & $\begin{array}{l}\text { Dummy variable: equals } 1 \text { when (1) the largest shareholder owns at least } 10 \% \text { of the voting rights; }(2) \\
\text { this shareholder is a government (direct ownership) or a government-owned company (ultimate } \\
\text { ownership, at the } 20 \% \text { threshold) (Source : Authors' database) }\end{array}$ \\
\hline TOBIN'S Q & $\begin{array}{l}\text { (Total assets - book value of common equity + market capitalization) / total assets (source : } \\
\text { Worldscope) }\end{array}$ \\
\hline VOLAT & Stock price volatility over the year, computed with monthly returns (Source : Datastream) \\
\hline$Y>2000$ & Dummy variable: equals 1 for the years 2001 to 2008 \\
\hline
\end{tabular}


Table 1: Descriptive statistics of sample firms

\section{Panel A: Board structures}

The sample comprises 3,054 firm-year observations from 379 SBF250 firms listed in France over the period 1998-2008.

\begin{tabular}{lccccccccccccc}
\hline & 1998 & 1999 & 2000 & 2001 & 2002 & 2003 & 2004 & 2005 & 2006 & 2007 & 2008 & Sample \\
\hline $\begin{array}{l}\text { Number of } \\
\text { firm-years }\end{array}$ & 201 & 243 & 282 & 309 & 308 & 297 & 285 & 281 & 286 & 285 & 277 & 3054 \\
DUAL & $18.9 \%$ & $19.3 \%$ & $20.2 \%$ & $25.2 \%$ & $27.6 \%$ & $27.9 \%$ & $28.1 \%$ & $28.8 \%$ & $26.6 \%$ & $24.9 \%$ & $24.2 \%$ & $25.0 \%$ \\
$\begin{array}{l}\text { UNITARY } \\
\begin{array}{l}\text { Al-Unified } \\
\text { positions }\end{array}\end{array}$ & $81.1 \%$ & $80.7 \%$ & $79.8 \%$ & $74.8 \%$ & $72.4 \%$ & $72.1 \%$ & $71.9 \%$ & $71.2 \%$ & $73.4 \%$ & $75.1 \%$ & $75.8 \%$ & $75.0 \%$ \\
$\begin{array}{l}\text { A2-Split } \\
\text { positions }\end{array}$ & $0.0 \%$ & $0.0 \%$ & $79.8 \%$ & $73.8 \%$ & $64.0 \%$ & $62.0 \%$ & $59.3 \%$ & $56.6 \%$ & $59.1 \%$ & $56.1 \%$ & $54.9 \%$ & $65.6 \%$ \\
\hline
\end{tabular}

\section{Panel B: Accounting, financial and ownership characteristics}

This panel provides mean and median values of firm characteristics. $* * *, * * *$ denote statistical significance based on twosided tests at the 1\%,5\% and 10\% level, respectively. Variable definitions are in the Appendix. Student t-statistics and Wilcoxon Z-statistics test for the difference in means and medians between categories.

\begin{tabular}{|c|c|c|c|c|c|c|c|c|c|c|c|}
\hline \multirow{3}{*}{ Number of firm-years } & \multirow{2}{*}{\multicolumn{3}{|c|}{ Total sample }} & \multirow{2}{*}{\multicolumn{2}{|c|}{$\begin{array}{l}\text { Unitary board } \\
2291\end{array}$}} & \multirow{2}{*}{\multicolumn{2}{|c|}{$\begin{array}{l}\text { Dual board } \\
763\end{array}$}} & \multirow{2}{*}{\multicolumn{4}{|c|}{ Tests for differences in }} \\
\hline & & & & & & & & & & & \\
\hline & mean & median & St Dev & mean & median & mean & median & means & & medians & \\
\hline MVE (M€) & 3934 & 402 & 11,935 & 4175 & 378 & 3209 & 488 & 1.94 & * & -2.58 & **** \\
\hline LOG(MVE) & 13.218 & 12.905 & 1.897 & 13.185 & 12.843 & 13.317 & 13.098 & -1.66 & $*$ & -2.58 & $* * *$ \\
\hline $\mathrm{R} \& \mathrm{D}$ & 312 & 0.000 & 0.464 & 0.343 & 0.000 & 0.221 & 0.000 & 6.29 & $* * *$ & 6.25 & $* * *$ \\
\hline VOLAT & 106 & 0.084 & 0.092 & 110 & 0.087 & 0.094 & 0.077 & 4.02 & $* * *$ & 4.55 & $* * *$ \\
\hline HIGHTECH & 147 & 0.000 & 0.355 & 0.172 & 0.000 & 0.073 & 0.000 & 6.70 & $* * *$ & 6.65 & $* * *$ \\
\hline AGE & & 11.000 & 20.8 & 16.998 & 11.000 & 21.810 & 13.000 & -5.54 & $* * *$ & -4.89 & $* * *$ \\
\hline LOG $(A$ & & & & 506 & 2.485 & 2.699 & 2.639 & -5.35 & $* * *$ & -4.89 & $* * *$ \\
\hline TOBIS & & 1.303 & & 1.749 & 1.306 & 1.499 & 1.286 & 3.62 & $* * *$ & 2.09 & $* *$ \\
\hline REL.SPREAD & 548 & 1.043 & & 1.596 & 1.043 & 1.402 & 1.044 & 1.42 & & 0.37 & \\
\hline MEI & & 0.000 & & & 0.000 & 0.092 & 0.000 & -4.40 & $* * *$ & -4.39 & $* * *$ \\
\hline$\% \mathrm{~S}$ & 115 & 0.009 & & 0.104 & 0.008 & 0.146 & 0.011 & -4.14 & *** & -4.36 & $* * *$ \\
\hline POP20 & & 0.000 & & 0.179 & 0.000 & 0.210 & 0.000 & -1.89 & $*$ & -1.89 & $*$ \\
\hline DUAL CLASS & & 0.000 & & 0.014 & 0.000 & 0.048 & 0.000 & -5.47 & $* * *$ & -5.45 & $* * *$ \\
\hline & & & & & 0.000 & 0.286 & 0.000 & -3.76 & $* * *$ & -3.75 & $* * *$ \\
\hline LEVI & & 0.230 & & 0.248 & 0.230 & 0.244 & 0.230 & 0.35 & & -0.89 & \\
\hline LISTING USA & 0.074 & 0.000 & & 0.086 & 0.000 & 0.037 & 0.000 & 4.56 & $* * *$ & 4.54 & $* * *$ \\
\hline & & & & & 0.467 & 32 & 0.461 & 0.21 & & 0.12 & \\
\hline & & & & & 1.000 & 0.721 & 1.000 & -2.00 & $* *$ & -2.00 & $* *$ \\
\hline STAT & & 0.000 & & 0.062 & 0.000 & 0.066 & 0.000 & -0.35 & & -0.35 & \\
\hline CHF & 0.642 & 1.000 & & 0.624 & 1.000 & 0.696 & 1.000 & -3.61 & $* * *$ & -3.60 & *** \\
\hline & & 0.000 & & & 0.000 & 0.422 & 0.000 & -14.15 & **** & -13.71 & $* * *$ \\
\hline & & 0.000 & & & 0.000 & 0.274 & 0.000 & 8.49 & $* * *$ & 8.40 & $* * *$ \\
\hline CHF.I & 0.273 & 0.000 & & 0.337 & 0.000 & 0.083 & 0.000 & 14.09 & $* * *$ & 13.65 & $* * *$ \\
\hline CHF.MGT.HEIRS & 0.130 & 0.000 & 0.336 & 0.109 & 0.000 & 0.191 & 0.000 & -5.89 & $* * *$ & -5.86 & $* * *$ \\
\hline
\end{tabular}


Table 2: The choice of board structure

This table presents a logit regression analysis of the choice of a dual board structure. The dependent variable equals 1 when the firm has a dual board structure. The sample contains 3,054 observations. Variable definitions are in the Appendix. Heteroskedastic-consistent z-statistics are in parentheses. Asterisks denote statistical significance at the $1 \%(* * *), 5 \%(* *)$, or $10 \%(*)$ level, respectively.

\begin{tabular}{|c|c|c|c|c|c|c|c|c|c|c|c|c|}
\hline \multirow{2}{*}{ Asymmetric Information } & \multicolumn{2}{|c|}{ Model 1} & \multicolumn{2}{|c|}{ Model 2} & \multicolumn{2}{|c|}{ Model 3} & \multicolumn{2}{|c|}{ Model 4} & \multicolumn{2}{|c|}{ Model 5} & \multicolumn{2}{|c|}{ Model 6} \\
\hline & & & & & & & & & & & & \\
\hline LOG(MVE) & $\begin{array}{r}0.068 \\
(2.54)\end{array}$ & $* *$ & $\begin{array}{r}0.052 \\
(1.84)\end{array}$ & $*$ & $\begin{array}{r}0.052 \\
(1.93)\end{array}$ & $*$ & $\begin{array}{l}0.072 \\
(2.60)\end{array}$ & $* * *$ & $\begin{array}{l}0.067 \\
(2.36)\end{array}$ & $* *$ & $\begin{array}{r}0.064 \\
(2.25)\end{array}$ & $* *$ \\
\hline $\mathrm{R} \& \mathrm{D}$ & $\begin{array}{l}-0.631 \\
(-5.40)\end{array}$ & $* * *$ & $\begin{array}{l}-0.628 \\
(-5.38)\end{array}$ & $* * *$ & $\begin{array}{l}-0.556 \\
(-4.72)\end{array}$ & $* * *$ & $\begin{array}{l}-0.563 \\
(-4.82)\end{array}$ & $* * *$ & $\begin{array}{l}-0.547 \\
(-4.57)\end{array}$ & $* * *$ & $\begin{array}{l}-0.551 \\
(-4.59)\end{array}$ & $* * *$ \\
\hline HIGHTECH & $\begin{array}{l}-1.123 \\
(-6.01)\end{array}$ & $* * *$ & $\begin{array}{l}-1.130 \\
(-6.03)\end{array}$ & $* * *$ & $\begin{array}{l}-1.023 \\
(-5.47)\end{array}$ & $* * *$ & $\begin{array}{l}-1.045 \\
(-5.59)\end{array}$ & $* * *$ & $\begin{array}{l}-1.126 \\
(-5.97)\end{array}$ & $* * *$ & $\begin{array}{l}-1.129 \\
(-5.97)\end{array}$ & $* * *$ \\
\hline VOLAT & $\begin{array}{l}-1.275 \\
(-1.87)\end{array}$ & $*$ & $\begin{array}{l}-1.188 \\
(-1.65)\end{array}$ & $*$ & $\begin{array}{l}-1.197 \\
(-1.80)\end{array}$ & $*$ & $\begin{array}{l}-1.086 \\
(-1.67)\end{array}$ & $*$ & $\begin{array}{l}-0.941 \\
(-1.47)\end{array}$ & & $\begin{array}{l}-0.944 \\
(-1.48)\end{array}$ & \\
\hline TOBIN'S Q & $\begin{array}{l}-0.097 \\
(-2.11)\end{array}$ & $* *$ & $\begin{array}{l}-0.096 \\
(-2.05)\end{array}$ & $* *$ & $\begin{array}{l}-0.104 \\
(-2.16)\end{array}$ & $* *$ & $\begin{array}{l}-0.111 \\
(-2.24)\end{array}$ & $* *$ & $\begin{array}{l}-0.114 \\
(-2.20)\end{array}$ & $* *$ & $\begin{array}{l}-0.113 \\
(-2.19)\end{array}$ & $* *$ \\
\hline LOG(AGE) & $\begin{array}{r}0.129 \\
(2.37)\end{array}$ & $* *$ & $\begin{array}{l}0.133 \\
(2.40)\end{array}$ & $* *$ & $\begin{array}{r}0.086 \\
(1.54)\end{array}$ & & $\begin{array}{r}0.112 \\
(1.96)\end{array}$ & $*$ & $\begin{array}{r}0.049 \\
(0.87)\end{array}$ & & $\begin{array}{r}0.051 \\
(0.91)\end{array}$ & \\
\hline REL.SPREAD & & & $\begin{array}{l}-0.023 \\
(-1.15)\end{array}$ & & & & & & & & & \\
\hline \multicolumn{13}{|l|}{ Private Benefits } \\
\hline MEDIA & & & & & $\begin{array}{l}0.688 \\
(3.83)\end{array}$ & $* * *$ & $\begin{array}{l}0.715 \\
(3.96)\end{array}$ & $* * *$ & $\begin{array}{r}0.750 \\
(4.19)\end{array}$ & $* * *$ & $\begin{array}{r}0.741 \\
(4.14)\end{array}$ & $* * *$ \\
\hline$\%$ SALES & & & & & $\begin{array}{l}0.421 \\
(2.47)\end{array}$ & $* *$ & & & $\begin{array}{l}0.421 \\
(2.45)\end{array}$ & $* *$ & $\begin{array}{l}0.429 \\
(2.50)\end{array}$ & $* *$ \\
\hline POP20 & & & & & & & $\begin{array}{l}0.442 \\
(3.82)\end{array}$ & $* * *$ & & & & \\
\hline DUAL CLASS & & & & & $\begin{array}{l}1.098 \\
(3.75)\end{array}$ & $* * *$ & $\begin{array}{l}1.199 \\
(4.17)\end{array}$ & $* * *$ & $\begin{array}{l}1.090 \\
(3.75)\end{array}$ & $* * *$ & $\begin{array}{l}1.082 \\
(3.75)\end{array}$ & $* * *$ \\
\hline \multicolumn{13}{|l|}{ Monitoring } \\
\hline LISTING USA & & & & & & & & & $\begin{array}{l}-0.947 \\
(-4.29)\end{array}$ & $* * *$ & $\begin{array}{l}-0.937 \\
(-4.23)\end{array}$ & $* * *$ \\
\hline LEVERAGE & & & & & & & & & $\begin{array}{l}-0.414 \\
(-1.74)\end{array}$ & $*$ & $\begin{array}{l}-0.404 \\
(-1.70)\end{array}$ & $*$ \\
\hline S1CFR & & & & & & & & & $\begin{array}{l}-0.571 \\
(-2.97)\end{array}$ & $* * *$ & & \\
\hline S1CFR*DBLE VR & & & & & & & & & & & $\begin{array}{l}-0.642 \\
(-3.11)\end{array}$ & $* * *$ \\
\hline S1CFR*(1-DBLE VR) & & & & & & & & & & & $\begin{array}{l}-0.435 \\
(-1.89)\end{array}$ & $*$ \\
\hline$Y>2000$ & $\begin{array}{l}0.429 \\
(3.93)\end{array}$ & $* * *$ & $\begin{array}{c}0.418 \\
(3.81)\end{array}$ & $* * *$ & $\begin{array}{l}0.448 \\
(4.02)\end{array}$ & $* * *$ & $\begin{array}{l}0.445 \\
(3.98)\end{array}$ & $* * *$ & $\begin{array}{l}0.469 \\
(4.16)\end{array}$ & $* * *$ & $\begin{array}{r}0.466 \\
(4.13)\end{array}$ & $* * *$ \\
\hline CONSTANT & $\begin{array}{l}-3.378 \\
(-6.65)\end{array}$ & $* * *$ & $\begin{array}{l}-3.151 \\
(-6.01)\end{array}$ & $* * *$ & $\begin{array}{l}-3.189 \\
(-6.20)\end{array}$ & $* * *$ & $\begin{array}{l}-3.612 \\
(-6.75)\end{array}$ & $* * *$ & $\begin{array}{l}-2.938 \\
(-5.38)\end{array}$ & $* * *$ & $\begin{array}{l}-2.903 \\
(-5.33)\end{array}$ & $* * *$ \\
\hline INDUSTRY & & & & & & & & & & & & \\
\hline DUMMIES & $\mathrm{Y}$ & & $\mathrm{Y}$ & & $\mathrm{Y}$ & & $\mathrm{Y}$ & & $\mathrm{Y}$ & & $\mathrm{Y}$ & \\
\hline Number of observations & 3054 & & 3048 & & 3054 & & 3054 & & 3054 & & 3054 & \\
\hline Pseudo $\mathrm{R}^{2}$ & 0.058 & & 0.058 & & 0.069 & & 0.071 & & 0.076 & & 0.076 & \\
\hline$\%$ Concordant & 0.753 & & 0.754 & & 0.754 & & 0.750 & & 0.758 & & 0.758 & \\
\hline Wald & 171.59 & $* * *$ & 170.00 & $* * *$ & 186.69 & $* * *$ & 190.63 & $* * *$ & 209.89 & $* * *$ & 210.86 & $* * *$ \\
\hline
\end{tabular}


Table 3: Board structure and closely held firms

This table presents a logit regression analysis of the choice of a dual board structure. The dependent variable equals 1 when the firm has a dual board structure. The total sample contains 3,054 observations. Regressions (4) and (5) are estimated for closely held firms only. Variable definitions are in the Appendix. Heteroskedastic-consistent z-statistics are in parentheses. Asterisks denote statistical significance at the $1 \%(* * *), 5 \%(* *)$, or $10 \%(*)$ level, respectively.

\begin{tabular}{|c|c|c|c|c|c|c|c|c|c|c|}
\hline Sample & \multicolumn{2}{|c|}{ Model 1} & \multicolumn{2}{|c|}{ Model 2} & \multicolumn{2}{|c|}{ Model 3} & \multicolumn{2}{|c|}{$\begin{array}{c}\text { Model 4 } \\
\text { Closely Held } \\
\text { Firms } \\
\end{array}$} & \multicolumn{2}{|c|}{$\begin{array}{c}\text { Model 5 } \\
\text { Closely Held } \\
\text { Firms } \\
\end{array}$} \\
\hline \multicolumn{11}{|c|}{ Asymmetric Information } \\
\hline LOG(MVE) & $\begin{array}{c}0.078 \\
(2.65)\end{array}$ & $* * *$ & $\begin{array}{c}0.058 \\
(1.96)\end{array}$ & $*$ & $\begin{array}{r}0.046 \\
(1.55)\end{array}$ & & $\begin{array}{r}0.017 \\
(0.45)\end{array}$ & & $\begin{array}{l}-0.051 \\
(-1.30)\end{array}$ & \\
\hline $\mathrm{R} \& \mathrm{D}$ & $\begin{array}{l}-0.524 \\
(-4.36)\end{array}$ & $* * *$ & $\begin{array}{l}-0.559 \\
(-4.53)\end{array}$ & $* * *$ & $\begin{array}{l}-0.592 \\
(-4.80)\end{array}$ & $* * *$ & $\begin{array}{l}-0.455 \\
(-3.08)\end{array}$ & $* * *$ & $\begin{array}{l}-0.529 \\
(-3.41)\end{array}$ & $* * *$ \\
\hline HIGHTECH & $\begin{array}{l}-1.082 \\
(-5.58)\end{array}$ & $* * *$ & $\begin{array}{l}-1.052 \\
(-5.18)\end{array}$ & $* * *$ & $\begin{array}{l}-0.887 \\
(-3.97)\end{array}$ & $* * *$ & $\begin{array}{l}-1.051 \\
(-4.74)\end{array}$ & $* * *$ & $\begin{array}{l}-0.489 \\
(-1.68)\end{array}$ & $*$ \\
\hline VOLAT & $\begin{array}{l}-0.928 \\
(-1.43)\end{array}$ & & $\begin{array}{l}-0.733 \\
(-1.32)\end{array}$ & & $\begin{array}{l}-0.538 \\
(-1.03)\end{array}$ & & $\begin{array}{l}-1.133 \\
(-1.36)\end{array}$ & & $\begin{array}{l}-0.393 \\
(-0.57)\end{array}$ & \\
\hline TOBIN'S Q & $\begin{array}{l}-0.116 \\
(-2.21)\end{array}$ & $* *$ & $\begin{array}{l}-0.093 \\
(-1.87)\end{array}$ & $*$ & $\begin{array}{l}-0.054 \\
(-1.45)\end{array}$ & & $\begin{array}{l}-0.079 \\
(-1.42)\end{array}$ & & $\begin{array}{l}-0.022 \\
(-0.80)\end{array}$ & \\
\hline LOG(AGE) & $\begin{array}{r}0.043 \\
(0.75)\end{array}$ & & $\begin{array}{l}-0.014 \\
(-0.24)\end{array}$ & & $\begin{array}{l}-0.124 \\
(-2.02)\end{array}$ & $* *$ & $\begin{array}{r}0.137 \\
(1.83)\end{array}$ & $*$ & $\begin{array}{l}-0.137 \\
(-1.70)\end{array}$ & $*$ \\
\hline \multicolumn{11}{|l|}{ Private Benefits } \\
\hline MEDIA & $\begin{array}{l}0.759 \\
(4.22)\end{array}$ & $* * *$ & $\begin{array}{c}0.623 \\
(3.30)\end{array}$ & $* * *$ & $\begin{array}{l}0.635 \\
(3.28)\end{array}$ & $* * *$ & $\begin{array}{l}1.164 \\
(4.79)\end{array}$ & $* * *$ & $\begin{array}{l}1.182 \\
(4.12)\end{array}$ & $* * *$ \\
\hline$\%$ SALES & $\begin{array}{l}0.405 \\
(2.39)\end{array}$ & $* *$ & $\begin{array}{l}0.676 \\
(3.56)\end{array}$ & $* * *$ & $\begin{array}{l}0.497 \\
(2.68)\end{array}$ & $* * *$ & $\begin{array}{l}0.592 \\
(3.26)\end{array}$ & $* * *$ & $\begin{array}{l}0.769 \\
(3.63)\end{array}$ & $* * *$ \\
\hline DUAL CLASS & $\begin{array}{l}1.038 \\
(3.40)\end{array}$ & $* * *$ & $\begin{array}{l}1.407 \\
(4.29)\end{array}$ & $* * *$ & $\begin{array}{l}1.044 \\
(3.21)\end{array}$ & $* * *$ & $\begin{array}{r}0.473 \\
(1.44)\end{array}$ & & $\begin{array}{l}0.427 \\
(1.26)\end{array}$ & \\
\hline EPONYMOUS & $\begin{array}{l}0.144 \\
(1.29)\end{array}$ & & $\begin{array}{l}0.294 \\
(2.49)\end{array}$ & $* *$ & $\begin{array}{l}0.154 \\
(1.31)\end{array}$ & & $\begin{array}{l}0.232 \\
(1.83)\end{array}$ & $*$ & $\begin{array}{l}0.302 \\
(2.26)\end{array}$ & $* *$ \\
\hline \multicolumn{11}{|l|}{ Monitoring } \\
\hline LISTING USA & $\begin{array}{l}-0.895 \\
(-4.03)\end{array}$ & $* * *$ & $\begin{array}{l}-0.899 \\
(-3.80)\end{array}$ & $* * *$ & $\begin{array}{l}-0.856 \\
(-3.50)\end{array}$ & $* * *$ & $\begin{array}{l}-1.308 \\
(-3.66)\end{array}$ & $* * *$ & $\begin{array}{l}-1.858 \\
(-4.59)\end{array}$ & $* * *$ \\
\hline LEVERAGE & $\begin{array}{l}-0.444 \\
(-1.83)\end{array}$ & $*$ & $\begin{array}{l}-0.590 \\
(-2.27)\end{array}$ & $* *$ & $\begin{array}{r}-0.256 \\
(-1.20)\end{array}$ & & $\begin{array}{l}-0.408 \\
(-1.19)\end{array}$ & & $\begin{array}{l}-0.221 \\
(-0.93)\end{array}$ & \\
\hline S1CFR & $\begin{array}{l}-0.730 \\
(-3.56)\end{array}$ & $* * *$ & $\begin{array}{l}-0.407 \\
(-1.91)\end{array}$ & $*$ & $\begin{array}{l}-0.472 \\
(-2.14)\end{array}$ & $* *$ & $\begin{array}{l}-1.446 \\
(-5.21)\end{array}$ & $* * *$ & $\begin{array}{l}-1.163 \\
(-3.81)\end{array}$ & $* * *$ \\
\hline \multicolumn{11}{|c|}{ Closely held firms attributes } \\
\hline $\mathrm{CHF}$ & $\begin{array}{r}0.306 \\
(2.74)\end{array}$ & $* * *$ & & & & & & & & \\
\hline PRO.MGT & & & $\begin{array}{l}1.042 \\
(8.54)\end{array}$ & $* * *$ & $\begin{array}{r}1.099 \\
(8.88)\end{array}$ & $* * *$ & & & $\begin{array}{r}2.692 \\
(14.87)\end{array}$ & $* * *$ \\
\hline CHF.MGT & & & $\begin{array}{l}-0.512 \\
(-3.90)\end{array}$ & $* * *$ & & & & & & \\
\hline CHF.MGT.GEN1 & & & & & $\begin{array}{l}-1.437 \\
(-8.06)\end{array}$ & $* * *$ & & & & \\
\hline CHF.MGT.HEIRS & & & & & $\begin{array}{r}0.614 \\
(3.87)\end{array}$ & $* * *$ & & & $\begin{array}{r}2.291 \\
(11.41)\end{array}$ & $* * *$ \\
\hline$Y>2000$ & $\begin{array}{r}0.480 \\
(4.26)\end{array}$ & $* * *$ & $\begin{array}{r}0.474 \\
(4.11)\end{array}$ & $* * *$ & $\begin{array}{r}0.528 \\
(4.49)\end{array}$ & $* * *$ & $\begin{array}{l}0.315 \\
(2.38)\end{array}$ & $* *$ & $\begin{array}{r}0.374 \\
(2.61)\end{array}$ & $* * *$ \\
\hline CONSTANT & $\begin{array}{l}-3.223 \\
(-5.83)\end{array}$ & $* * *$ & $\begin{array}{l}-2.829 \\
(-5.16)\end{array}$ & $* * *$ & $\begin{array}{l}-2.554 \\
(-4.46)\end{array}$ & $* * *$ & $\begin{array}{l}-1.460 \\
(-2.27)\end{array}$ & $* *$ & $\begin{array}{l}-1.866 \\
(-2.61)\end{array}$ & $* * *$ \\
\hline \multicolumn{11}{|l|}{ INDUSTRY } \\
\hline DUMMIES & $\mathrm{Y}$ & & $\mathrm{Y}$ & & $\mathrm{Y}$ & & $\mathrm{Y}$ & & $\mathrm{Y}$ & \\
\hline Number of observations & 3054 & & 3054 & & 3054 & & 1960 & & 1960 & \\
\hline Pseudo $\mathrm{R}^{2}$ & 0.079 & & 0.131 & & 0.168 & & 0.080 & & 0.214 & \\
\hline$\%$ Concordant & 0.761 & & 0.758 & & 0.775 & & 0.737 & & 0.776 & \\
\hline Wald & 219.24 & $* * *$ & 340.47 & $* * *$ & 417.33 & $* * *$ & 161.98 & $* * *$ & 358.21 & $* * *$ \\
\hline
\end{tabular}


Table 4: Board structure: dual board versus unitary board with split positions

This table presents a sequential logit regression analysis of the choice of a board structure. In the first step, the dependent variable equals 1 when the firm has a dual board structure; in the second step, the dependent variable equals 1 when the CEO and Chairman positions are split. As the separation of the Chairman and CEO positions became possible in 2001, the sample is restricted to the period 2001 to 2008. Variable definitions are in the Appendix. Heteroskedastic-consistent z-statistics are in parentheses. Asterisks denote statistical significance at the $1 \%(* * *), 5 \%(* *)$, or $10 \%$ (*) level, respectively.

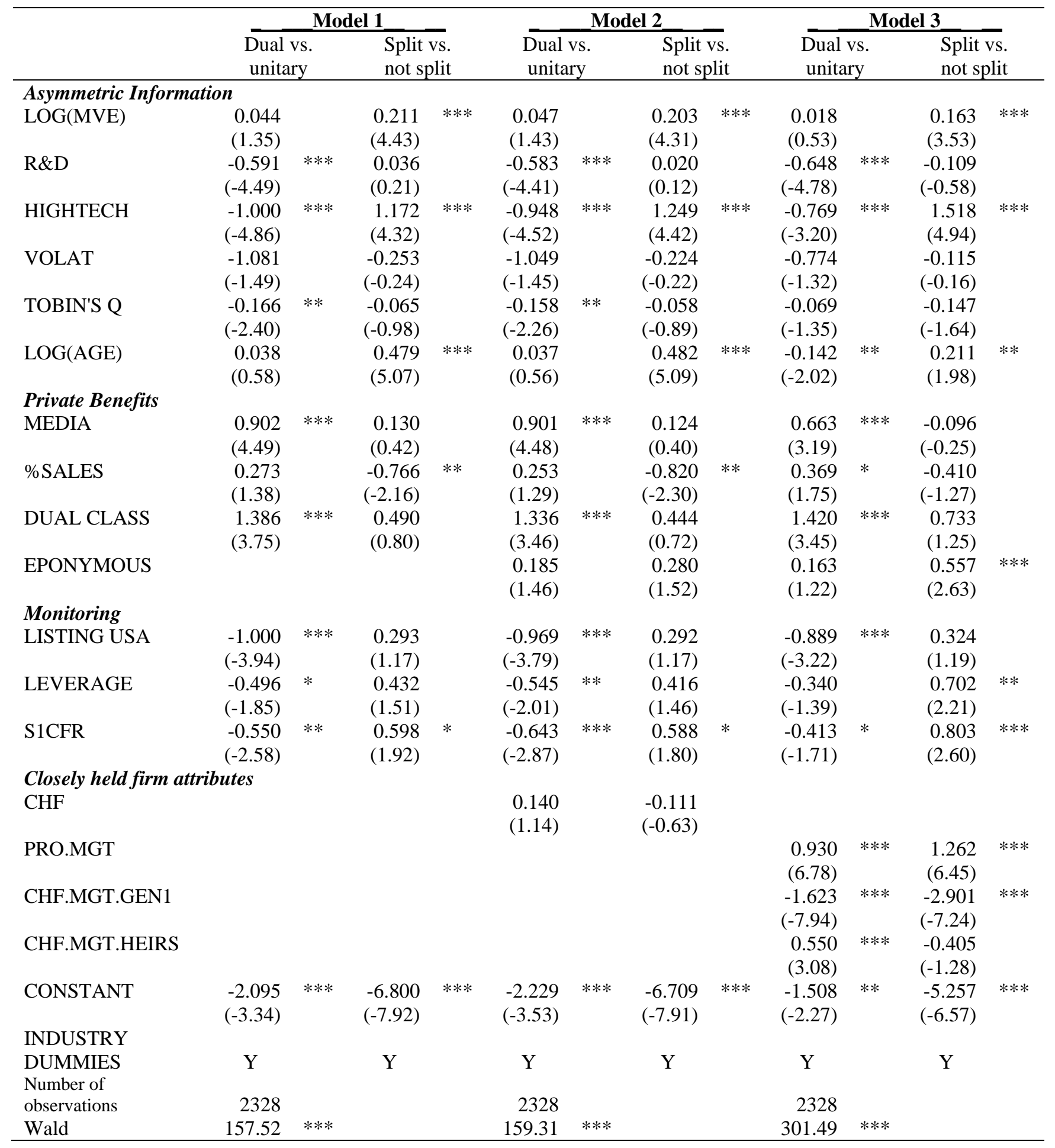


Table 5: CEO turnover and board structure

This table presents a logit regression analysis of CEO turnover as function of the firm's board structure. The dependent variable equals 1 if the firm's CEO leaves the CEO position during the following year. The total sample contains 2,939 firm-year observations, during which there were 293 cases of CEO turnover. The reduced number of firm-year observations is due to missing data about CEO characteristics. Variable definitions are in the Appendix.

Heteroskedastic-consistent z-statistics are in parentheses. Asterisks denote statistical significance at the $1 \%(* * *), 5 \%$ (**), or $10 \%(*)$ level, respectively.

\begin{tabular}{|c|c|c|c|c|c|c|c|c|c|c|c|c|}
\hline \multirow[b]{2}{*}{ PERF } & \multicolumn{2}{|c|}{ Model 1} & \multicolumn{2}{|c|}{ Model 2} & \multicolumn{2}{|c|}{ Model 3} & \multicolumn{2}{|c|}{ Model 4} & \multicolumn{2}{|c|}{ Model 5} & \multicolumn{2}{|c|}{ Model 6} \\
\hline & $\begin{array}{l}-0.677 \\
(-2.79)\end{array}$ & $* * *$ & $\begin{array}{l}-0.514 \\
(-2.06)\end{array}$ & $* *$ & $\begin{array}{l}-0.669 \\
(-2.68)\end{array}$ & $* * *$ & $\begin{array}{l}-0.494 \\
(-1.94)\end{array}$ & $*$ & $\begin{array}{l}-0.517 \\
(-2.08)\end{array}$ & $* *$ & $\begin{array}{l}-0.744 \\
(-2.61)\end{array}$ & $* * *$ \\
\hline DS & & & $\begin{array}{r}0.216 \\
(1.33)\end{array}$ & & & & $\begin{array}{r}0.282 \\
(1.65)\end{array}$ & $*$ & $\begin{array}{r}0.109 \\
(0.68)\end{array}$ & & $\begin{array}{r}0.221 \\
(1.36)\end{array}$ & \\
\hline PERF*DS & & & $\begin{array}{l}-0.951 \\
(-2.05)\end{array}$ & $* *$ & & & $\begin{array}{l}-0.973 \\
(-2.09)\end{array}$ & $* *$ & $\begin{array}{l}-0.947 \\
(-2.07)\end{array}$ & $* *$ & $\begin{array}{l}-0.945 \\
(-2.06)\end{array}$ & $* *$ \\
\hline $\mathrm{A} 2$ & & & & & $\begin{array}{c}0.158 \\
(0.64)\end{array}$ & & $\begin{array}{r}0.311 \\
(1.19)\end{array}$ & & & & & \\
\hline PERF*A2 & & & & & $\begin{array}{l}-0.145 \\
(-0.15)\end{array}$ & & $\begin{array}{l}-0.325 \\
(-0.34)\end{array}$ & & & & & \\
\hline S1CFR & $\begin{array}{r}0.041 \\
(0.15)\end{array}$ & & $\begin{array}{r}0.067 \\
(0.25)\end{array}$ & & $\begin{array}{r}0.043 \\
(0.16)\end{array}$ & & $\begin{array}{r}0.072 \\
(0.27)\end{array}$ & & $\begin{array}{l}0.231 \\
(0.87)\end{array}$ & & $\begin{array}{l}0.068 \\
(0.26)\end{array}$ & \\
\hline $\mathrm{CHF}$ & $\begin{array}{l}-0.821 \\
(-5.25)\end{array}$ & $* * *$ & $\begin{array}{l}-0.861 \\
(-5.47)\end{array}$ & $* * *$ & $\begin{array}{l}-0.829 \\
(-5.28)\end{array}$ & $* * *$ & $\begin{array}{l}-0.884 \\
(-5.56)\end{array}$ & $* * *$ & & & $\begin{array}{l}-0.853 \\
(-5.39)\end{array}$ & $* * *$ \\
\hline PRO.MGT & & & & & & & & & $\begin{array}{l}-0.446 \\
(-2.64)\end{array}$ & $* * *$ & & \\
\hline CHF.MGT & & & & & & & & & $\begin{array}{l}-1.353 \\
(-6.92)\end{array}$ & $* * *$ & & \\
\hline PERF*CHF & & & & & & & & & & & $\begin{array}{r}0.382 \\
(1.04)\end{array}$ & \\
\hline LOG(MVE) & $\begin{array}{l}-0.018 \\
(-0.46)\end{array}$ & & $\begin{array}{l}-0.018 \\
(-0.45)\end{array}$ & & $\begin{array}{l}-0.020 \\
(-0.52)\end{array}$ & & $\begin{array}{l}-0.023 \\
(-0.59)\end{array}$ & & $\begin{array}{l}-0.026 \\
(-0.71)\end{array}$ & & $\begin{array}{l}-0.017 \\
(-0.45)\end{array}$ & \\
\hline VOLAT & $\begin{array}{r}2.256 \\
(2.67)\end{array}$ & $* * *$ & $\begin{array}{l}2.414 \\
(2.86)\end{array}$ & $* * *$ & $\begin{array}{r}2.272 \\
(2.70)\end{array}$ & $* * *$ & $\begin{array}{r}2.478 \\
(2.94)\end{array}$ & $* * *$ & $\begin{array}{r}2.767 \\
(3.27)\end{array}$ & $* * *$ & $\begin{array}{l}2.338 \\
(2.82)\end{array}$ & $* * *$ \\
\hline CEO AGE & $\begin{array}{l}2.495 \\
(4.87)\end{array}$ & $* * *$ & $\begin{array}{l}2.571 \\
(4.92)\end{array}$ & $* * *$ & $\begin{array}{l}2.517 \\
(4.89)\end{array}$ & $* * *$ & $\begin{array}{l}2.629 \\
(4.97)\end{array}$ & $* * *$ & $\begin{array}{r}2.479 \\
(4.61)\end{array}$ & $* * *$ & $\begin{array}{l}2.570 \\
(4.91)\end{array}$ & $* * *$ \\
\hline CEO TENURE & $\begin{array}{l}0.008 \\
(0.12)\end{array}$ & & $\begin{array}{l}0.036 \\
(0.48)\end{array}$ & & $\begin{array}{r}0.023 \\
(0.31)\end{array}$ & & $\begin{array}{l}0.072 \\
(0.89)\end{array}$ & & $\begin{array}{l}0.144 \\
(1.80)\end{array}$ & $*$ & $\begin{array}{l}0.037 \\
(0.49)\end{array}$ & \\
\hline CONSTANT & $\begin{array}{l}-12.38 \\
(-5.84)\end{array}$ & $* * *$ & $\begin{array}{l}-12.76 \\
(-5.88)\end{array}$ & $* * *$ & $\begin{array}{l}-12.46 \\
(-5.85)\end{array}$ & $* * *$ & $\begin{array}{l}-12.99 \\
(-5.91)\end{array}$ & $* * *$ & $\begin{array}{l}-12.55 \\
(-5.65)\end{array}$ & $* * *$ & $\begin{array}{l}-12.75 \\
(-5.88)\end{array}$ & $* * *$ \\
\hline INDUSTRY & & & & & & & & & & & & \\
\hline DUMMIES & $\mathrm{Y}$ & & $\mathrm{Y}$ & & $\mathrm{Y}$ & & $\mathrm{Y}$ & & $\mathrm{Y}$ & & $\mathrm{Y}$ & \\
\hline YEAR DUMMIES & $\mathrm{Y}$ & & $\mathrm{Y}$ & & $\mathrm{Y}$ & & $\mathrm{Y}$ & & $\mathrm{Y}$ & & $\mathrm{Y}$ & \\
\hline $\begin{array}{l}\text { Number of } \\
\text { observations }\end{array}$ & 2939 & & 2939 & & 2939 & & 2939 & & 2939 & & 2939 & \\
\hline Pseudo $\mathrm{R}^{2}$ & 0.057 & & 0.061 & & 0.057 & & 0.062 & & 0.071 & & 0.061 & \\
\hline$\%$ Concordant & 0.900 & & 0.900 & & 0.900 & & 0.900 & & 0.900 & & 0.900 & \\
\hline Wald & 86.90 & $* * *$ & 91.61 & $* * *$ & 88.13 & $* * *$ & 94.38 & $* * *$ & 110.92 & $* * *$ & 98.03 & $* * *$ \\
\hline
\end{tabular}


Table 6: Robustness checks

This table presents a logit regression analysis of the choice of a dual board structure. The dependent variable equals 1 when the firm has a dual board structure. The total sample contains 3,054 observations. In model 2, the sample is restricted to firms which never experienced a change of their board structure over the years 1998 to 2008 . In model 3, financial companies (i.e., firms with a 1-digit SIC code equal to 6) are excluded. In model 4, year dummies are included. In model 5, the sample is restricted to the period 2001-2008. Variable definitions are in the Appendix. Heteroskedasticconsistent $\mathrm{z}$-statistics are in parentheses. Asterisks denote statistical significance at the $1 \%(* * *), 5 \%(* *)$, or $10 \%(*)$ level, respectively.

\begin{tabular}{|c|c|c|c|c|c|c|c|c|c|c|}
\hline \multirow{2}{*}{$\begin{array}{l}\text { Sample } \\
\text { Asymmetric Informatio }\end{array}$} & \multicolumn{2}{|c|}{$\begin{array}{l}\text { Model } 1 \\
\text { Total }\end{array}$} & \multicolumn{2}{|c|}{$\begin{array}{c}\text { Model 2 } \\
\text { No Change in } \\
\text { Structure } \\
\end{array}$} & \multicolumn{2}{|c|}{$\begin{array}{c}\text { Model 3 } \\
\text { Non Financial } \\
\text { Firms Only } \\
\end{array}$} & \multicolumn{2}{|c|}{$\begin{array}{c}\text { Model } 4 \\
\text { Total with Year } \\
\text { Dummies } \\
\end{array}$} & \multicolumn{2}{|c|}{$\begin{array}{c}\text { Model 5 } \\
\text { Year>2000 }\end{array}$} \\
\hline & & & & & & & & & & \\
\hline \multirow[t]{2}{*}{ LOG(MVE) } & 0.030 & & 0.175 & $* * *$ & -0.023 & & 0.031 & & -0.001 & \\
\hline & $(0.99)$ & & $(3.65)$ & & $(-0.70)$ & & $(1.01)$ & & $(-0.02)$ & \\
\hline \multirow[t]{2}{*}{$\mathrm{R} \& \mathrm{D}$} & -0.607 & $* * *$ & -0.735 & $* * *$ & -0.558 & $* * *$ & -0.594 & $* * *$ & -0.657 & $* * *$ \\
\hline & $(-4.85)$ & & $(-3.90)$ & & $(-4.46)$ & & $(-4.69)$ & & $(-4.78)$ & \\
\hline \multirow[t]{2}{*}{ HIGHTECH } & -0.890 & $* * *$ & -1.313 & $* * *$ & -0.951 & $* * *$ & -0.889 & $* * *$ & -0.772 & $* * *$ \\
\hline & $(-4.01)$ & & $(-3.27)$ & & $(-4.14)$ & & $(-3.97)$ & & $(-3.23)$ & \\
\hline \multirow[t]{2}{*}{ VOLAT } & -0.586 & & 1.716 & $*$ & -0.563 & & -0.558 & & -0.816 & \\
\hline & $(-1.08)$ & & $(1.81)$ & & $(-1.02)$ & & $(-1.05)$ & & $(-1.33)$ & \\
\hline \multirow[t]{2}{*}{ TOBIN'S Q } & -0.043 & & -0.081 & & -0.030 & & -0.049 & & -0.057 & \\
\hline & $(-1.32)$ & & $(-1.19)$ & & $(-1.02)$ & & $(-1.43)$ & & $(-1.32)$ & \\
\hline \multirow[t]{2}{*}{ LOG(AGE) } & -0.113 & $*$ & -0.046 & & -0.016 & & -0.112 & $*$ & -0.135 & $*$ \\
\hline & $(-1.84)$ & & $(-0.53)$ & & $(-0.25)$ & & $(-1.83)$ & & $(-1.92)$ & \\
\hline \multicolumn{11}{|l|}{ Private Benefits } \\
\hline \multirow[t]{2}{*}{ MEDIA } & 0.715 & $* * *$ & 1.422 & $* * *$ & 0.765 & $* * *$ & 0.720 & $* * *$ & 0.736 & $* * *$ \\
\hline & $(3.61)$ & & $(4.35)$ & & $(3.78)$ & & $(3.62)$ & & $(3.45)$ & \\
\hline \multirow[t]{2}{*}{$\%$ SALES } & 0.474 & $* *$ & 0.190 & & 0.387 & $*$ & 0.484 & $* * *$ & 0.341 & \\
\hline & $(2.57)$ & & $(0.75)$ & & $(1.92)$ & & $(2.63)$ & & $(1.63)$ & \\
\hline \multirow[t]{2}{*}{ DUAL CLASS } & 0.975 & $* * *$ & 0.772 & & 1.053 & $* * *$ & 0.979 & $* * *$ & 1.307 & $* * *$ \\
\hline & $(3.12)$ & & $(1.23)$ & & (2.94) & & (3.11) & & $(3.30)$ & \\
\hline \multirow[t]{2}{*}{ EPONYMOUS } & 0.184 & & 0.610 & $* * *$ & 0.207 & $*$ & 0.184 & & 0.195 & \\
\hline & $(1.55)$ & & $(3.55)$ & & $(1.74)$ & & $(1.55)$ & & $(1.44)$ & \\
\hline \multicolumn{11}{|l|}{ Monitoring } \\
\hline \multirow[t]{2}{*}{ LISTING USA } & -0.831 & $* * *$ & -0.192 & & -1.291 & $* * *$ & -0.868 & $* * *$ & -0.866 & $* * *$ \\
\hline & $(-3.36)$ & & $(-0.64)$ & & $(-4.23)$ & & $(-3.47)$ & & $(-3.11)$ & \\
\hline LEVERAGE & -0.254 & & 0.081 & & -0.552 & $* *$ & -0.261 & & -0.343 & \\
\hline & $(-1.23)$ & & $(0.33)$ & & $(-2.12)$ & & $(-1.25)$ & & $(-1.44)$ & \\
\hline S1CFR & -0.616 & $* * *$ & -1.043 & $* * *$ & -0.816 & $* * *$ & -0.620 & $* * *$ & -0.551 & $* *$ \\
\hline & $(-2.70)$ & & $(-3.09)$ & & $(-3.23)$ & & $(-2.71)$ & & $(-2.19)$ & \\
\hline PRO.MGT & 1.237 & $* * *$ & 1.713 & $* * *$ & 1.215 & $* * *$ & 1.248 & $* * *$ & 1.057 & $* * *$ \\
\hline & $(9.24)$ & & $(7.68)$ & & $(8.00)$ & & $(9.29)$ & & (7.10) & \\
\hline CHF.MGT.GEN1 & -1.294 & $* * *$ & -0.934 & $* * *$ & -1.315 & $* * *$ & -1.294 & $* * *$ & -1.493 & $* * *$ \\
\hline & $(-6.95)$ & & $(-3.55)$ & & $(-6.62)$ & & $(-6.94)$ & & $(-7.03)$ & \\
\hline CHF.MGT.HEIRS & 0.778 & $* * *$ & 1.453 & $* * *$ & 0.766 & $* * *$ & 0.774 & $* * *$ & 0.705 & $* * *$ \\
\hline & (4.61) & & (5.99) & & $(4.22)$ & & (4.59) & & $(3.69)$ & \\
\hline Others & & & & & & & & & & \\
\hline STATE & 0.701 & $* * *$ & 1.150 & $* * *$ & 0.647 & $* * *$ & 0.696 & $* * *$ & 0.655 & $* * *$ \\
\hline & $(3.31)$ & & $(3.60)$ & & $(2.79)$ & & $(3.29)$ & & $(2.74)$ & \\
\hline$Y>2000$ & 0.537 & $* * *$ & 0.225 & & 0.504 & $* * *$ & & & & \\
\hline & $(4.57)$ & & $(1.39)$ & & $(3.91)$ & & & & & \\
\hline CONSTANT & -2.461 & $* * *$ & -4.516 & $* * *$ & -1.803 & $* * *$ & -2.648 & $* * *$ & -1.324 & $* *$ \\
\hline & $(-4.30)$ & & $(-5.87)$ & & $(-2.96)$ & & $(-4.44)$ & & $(-1.97)$ & \\
\hline INDUSTRY & $\mathrm{Y}$ & & $\mathrm{Y}$ & & $\mathrm{Y}$ & & $\mathrm{Y}$ & & $\mathrm{Y}$ & \\
\hline DUMMIES & & & & & & & & & & \\
\hline YEAR DUMMIES & $\mathrm{N}$ & & $\mathrm{N}$ & & $\mathrm{N}$ & & $\mathrm{Y}$ & & $\mathrm{N}$ & \\
\hline Number of observations & 3054 & & 1686 & & 2650 & & 3054 & & 2328 & \\
\hline Pseudo R ${ }^{2}$ & 0.171 & & 0.238 & & 0.190 & & 0.172 & & 0.169 & \\
\hline$\%$ Concordant & 0.782 & & 0.821 & & 0.792 & & 0.783 & & 0.774 & \\
\hline Wald & 422.13 & $* * *$ & 318.49 & $* * *$ & 383.79 & $* * *$ & 427.60 & $* * *$ & 306.38 & $* * *$ \\
\hline
\end{tabular}

